\title{
Organizational Commitment among Public and Private School Teachers
}

\author{
Sadia $\operatorname{Khan}^{1}$
}

\section{ABSTRACT:}

An attempt was made to study the organizational commitment among public and private school teachers. The data was collected from 150 school teachers, including 75 each from public and private schools through random sampling technique. Organizational Commitment Scale developed by Shawkat and Ansari (2001) was used for data collection. Analyses of the data were done by applying Mean, SD and t-test. Results revealed the significant difference between organizational commitment of public and private school teachers. It was also found that private school teachers experienced more commitment as compared to the public school teachers.

Keywords: Organizational Commitment, Public and Private School Teachers.

\section{Organizational Commitment}

Sheldon (1971) defined commitment as "an attitude or an orientation towards the organization, which links or attached the identification of the person to the organization". Organizational commitment is a powerful tool that can be applied as an aid to achieved higher level of performance and to developed and maintain discipline in an organization. The construct has been found to be related to many important outcome variables such as; performance, absenteeism, employees' turnover, tardiness etc. Lack of commitment towards the work and the organization can be contributed to the major problems experienced by organizations like high cost of production and poor services (Sherwin, 1972). Blau \& Boal (1987) defined organizational commitment as 'a state in which an employee identities with a particular organization and its goals, and wishes to maintain membership in the organization'. According to Riechers (1985) commitment to an organization constituted with three major attitudes such as: (1) a sense of identification with the organization's goals. (2) A feeling of involvement in organization's duties and (3) a feeling of loyalty for the organization. Sharma \& Singh (1991) argued that organizational commitment is the product of two independent sets of factors viz; personal and organizational, which simultaneously operate in every organization. Miller and Lee (2001) stated that organizational commitment is a state of being, in which organizational members are bound-

\footnotetext{
${ }^{1}$ Research Scholar, Department of Psychology, Aligarh Muslim University, Aligarh-202002 (India)
} 
- by their actions and beliefs that sustain their activities and their own involvement in the organization. Maume (2006) defined organizational commitment as " it is typically measured by items tapping respondents' willingness to work hard to improve their companies, the fit between the firm's and the worker's values, reluctance to leave and loyalty toward pride taken in working for their employers".

\section{Dimensions of Organizational Commitment}

Meyer and Allen (1997) proposed three dimensions to understand the organizational commitment namely, Affective, Continuance and Normative Commitments. The brief description of these dimension are presented as:

\section{Affective Commitment}

Meyer and Allen (1997) defined affective commitment as 'the employee's emotional attachment to, identification with, and involvement in the organization". Organizational members, who are committed to an organization on an affective basis, continue working for the organization because they want to (Meyer and Allen, 1991). Employees who are committed on an affective level stay with the organization because they realized their personal employment relationship as congruent to the goals and values of the organization (Beck and Wilson, 2000).

\section{Continuance Commitment}

According to Meyer and Allen (1997) continuance commitment is "the awareness of the costs associated with leaving the organization". It is calculative in nature because, the individual's perception or weighting of costs and risks related with leaving the current organization (Meyer and Allen, 1997). Meyer and Allen (1991) further pointed that "employees whose primary link to the organization is based on continuance commitment remain because they need to do so'. This indicated the difference between continuance and affective commitment in the organization.

\section{Normative Commitment}

Meyer and Allen (1997) stated normative commitment as "a feeling of obligation to continue employment". Internalized normative beliefs of duty and obligation make individuals obliged to sustain membership in the organization (Allen and Meyer, 1990). According to Meyer and Allen (1991) point of view "employee with normative commitment feels that they ought to remain with the organization".

\section{LITERATURE REVIEW}

Luthans et al. (1992) conducted a study to find out the importance of social support on employees' commitment. They found strong positive correlation between strong supportive climate and bank teller's organizational commitment. 
In a study, Pedro (1992) found that the teachers' motivation emerged as most powerful predictor of organizational commitment. Findings also indicated that female teachers tend to have higher commitment than male teachers.

Fresko, Kfir and Nasser (1997) conducted a study to find the effect of job satisfaction on organizational commitment. Results revealed that only job satisfaction could directly predicted organizational commitment. On the other hand, Mathew (2003) conducted the study to evaluate the teachers work values. The findings showed that those teachers who have high work values were more committed to the organization.

Suki and Suki (2011) conducted a study to find out the influence of gender on employee's perception of job satisfaction and organizational commitment. Findings revealed that employee's gender has no significant effect on his/her perception of job satisfaction. Further they found that men and women employees have the same level of organizational commitment.

Kumari and Jafri (2011) conducted a study to measure the level of overall organizational commitment of male and female secondary school teachers in Aligarh Muslim University, Aligarh. Data was analyzed by applying Mean, SD and t-test. Results showed that overall percentage of female school teachers experienced higher level of organizational commitment as compared to the male teachers. Similar results were found by Zilli and Zahoor (2012) among male and female higher education teachers.

Nagar (2012) conducted a study to evaluate "organizational commitment and job satisfaction among teachers during times of Burnout for developing and tests a model for Burnout and its influence on job satisfaction and organizational commitment". Results showed that with the consideration of job satisfaction \& organizational commitment, the mean score of female teachers was found to be higher than male teachers. He concluded that greater job satisfaction among teachers also leads to the increased level of organizational commitment.

Misra, Ansari and Khan (2009) conducted the study to measure the organizational commitment among Government and private school teachers. They reported that the private school teachers showed higher organizational commitment as compared to the government school teachers.

Gupta and Gehlawat (2013) conducted the study to assess the influence of job satisfaction, work motivation and type of schools on organizational commitment among the sample of 480 secondary school teachers in Rohtak Division of Haryana. The investigators applied Means, SD's and t-test for analyzing the collected data. Findings of the study reported significant effect of type of schools and job satisfaction on the organizational commitment of the teachers. Private school teachers significantly differ with Government school teachers and they possessed higher level of organizational commitment as compared to the Government school 
teachers. Further, there was no significant difference was found in organizational commitment of private school teachers with high and low level of work motivation and the government school teachers with high level of work motivation were reported to be better than their counterparts with respect to their organizational commitment.

Although, a large number of the research investigations have been done on organizational commitment among employees working in different organizational as well as industrial set-ups but much has not been done on organizational commitment among public and private school teachers teaching in various schools in Aligarh. Therefore, the present investigation has been designed to explore the organizational commitment among public and private school teachers to find out the effect of school structure on teachers' commitment.

\section{OBJECTIVES:}

Objectives of the study are stated as follows:

$>$ To determine the overall organizational commitment among public and private school teachers.

$>$ To determine the affective commitment dimension among public and private school teachers.

$>$ To determine the continuance commitment dimension among public and private school teachers.

$>$ To determine the normative commitment dimension among public and private school teachers.

\section{HYPOTHESES}

$>$ There will be significant difference between overall organizational commitment of public and private school teachers.

$>$ There will be significant difference between affective commitment dimension of public and private school teachers.

$>$ There will be significant difference between continuance commitment dimension of public and private school teachers.

$>$ There will be significant difference between normative commitment dimension of public and private school teachers.

\section{Sample of the Study}

The sample of the present study was drawn from public and private schools. The sample comprising of 150-school teachers (75-working in public and 75-in private schools) were selected by applying random sampling technique from Aligarh district of Uttar Pradesh. 


\section{Tool Used}

In the present investigation organizational commitment scale was used for data collection. The brief description of the scale is as follows:

\section{Organizational Commitment Scale}

This scale was developed by Shawkat and Ansari (2001). It contains with 15 items and each items to be rated on seven point scale ranging from strongly agree to the strongly disagree. This scale is having 3 dimensions-Affective Commitment, Continuance Commitment and Normative Commitment. Items 1 to 5 falls under affective commitment, 6 to 10 falls under continuance commitment and 11 to 15 falls under normative commitment. The split half reliability of this scale was found to be 0.80 and the congruent validity was found to be 0.76 .

\section{Procedure of Data Collection}

Good rapport was established with each teacher before requesting to fill up the questionnaire and then instructions were invariably explained to the teachers. After that questionnaires were distributed individually. Subjects were assured of confidentiality of their responses and were requested to extend their co-operation. Finally questionnaires were collected from all the teachers, scoring done and analysis was carried on.

\section{Statistical Analyses}

To meet the research hypotheses Mean, SD and t-test were applied.

\section{RESULTS AND INTERPRETATION}

Table-1: Showing Mean, SD and t-value of Public and Private school teachers on overall organizational commitment.

\begin{tabular}{|l|l|l|l|l|l|}
\hline Variable & Groups & N & Mean & SD & $\begin{array}{l}\text { t-value } \\
\text { (df=148) }\end{array}$ \\
\hline \multirow{2}{*}{$\begin{array}{l}\text { Organizational } \\
\text { commitment }\end{array}$} & $\begin{array}{l}\text { Private } \\
\text { School } \\
\text { Teachers }\end{array}$ & 75 & 81.50 & 8.47 & \multirow{2}{*}{$4.47^{* *}$} \\
\cline { 2 - 5 } & $\begin{array}{l}\text { Public } \\
\text { School } \\
\text { Teachers }\end{array}$ & 75 & 74.88 & 9.63 & \\
\hline
\end{tabular}

**Significant at0 .01 level 
Table-1 showing mean difference between organizational commitment of teachers working in Public and Private sector schools. The mean value for private school teachers was found to be 81.50 with the SD as 8.47. Similarly, the mean value for the public school teachers was found to be 74.88 with SD as 9.63 respectively. The t-value between two means was found to be 4.47 which was significant at 0.01level of significance. Thus, the first underlined hypothesis of the present investigation that (there will be significant difference between overall organizational commitment of public and private school teachers) is proved. The teachers of private schools have been found more committed than public school teachers.

Table-2: Showing Mean, SD and t-value of Public and Private school teachers on dimensions of organizational commitment.

\begin{tabular}{|c|c|c|c|c|c|}
\hline $\begin{array}{l}\text { Dimension of } \\
\text { Organizational } \\
\text { Commitment }\end{array}$ & Groups & $\mathbf{N}$ & Mean & SD & $\begin{array}{l}\text { t-value } \\
(\mathrm{df}=148)\end{array}$ \\
\hline \multirow[t]{2}{*}{$\begin{array}{l}\text { Affective } \\
\text { Commitment }\end{array}$} & $\begin{array}{l}\text { Private } \\
\text { School } \\
\text { Teachers }\end{array}$ & 75 & 27.08 & 3.44 & \multirow[t]{2}{*}{$2.10^{*}$} \\
\hline & $\begin{array}{l}\text { Public } \\
\text { School } \\
\text { Teachers }\end{array}$ & 75 & 23.90 & 2.65 & \\
\hline \multirow[t]{2}{*}{$\begin{array}{l}\text { Continuance } \\
\text { commitment }\end{array}$} & $\begin{array}{l}\text { Private } \\
\text { School } \\
\text { Teachers }\end{array}$ & 75 & 26.94 & 3.35 & \multirow[t]{2}{*}{1.89} \\
\hline & $\begin{array}{l}\text { Public } \\
\text { School } \\
\text { Teachers }\end{array}$ & 75 & 25.50 & 5.68 & \\
\hline \multirow[t]{2}{*}{$\begin{array}{l}\text { Normative } \\
\text { Commitment }\end{array}$} & $\begin{array}{l}\text { Private } \\
\text { School } \\
\text { Teachers }\end{array}$ & 75 & 27.48 & 3.54 & \multirow[t]{2}{*}{$2.84 * *$} \\
\hline & $\begin{array}{l}\text { Public } \\
\text { School } \\
\text { Teachers }\end{array}$ & 75 & 25.46 & 5.07 & \\
\hline
\end{tabular}

*Significant at 0.05 level

**Significant at0 .01 level

Table-2 is showing the mean difference between on various dimensions of organizational commitment of Public and Private school teachers. The Mean and SD in the case of private school teachers on affective commitment dimension were found to be 27.08 and 3.44 , while in the case of public school teachers were found to be 23.90 and 2.65 respectively. The t-value 
between two means was found to b2.10 which was significant at 0.05 level of significance. Thus, the second underlined hypothesis of the present investigation that (there will be significant difference between affective commitment dimension of public and private school teachers) is proved.

The Mean and SD in the case of private school teachers on continuance commitment dimension were found to be 26.94 and 3.35, while in the case of public school teachers were found to be 25.50 and 5.68 respectively. The t-value between two means was found to b1.89 which was not significant even at 0.05 level of significance. Thus, the third underlined hypothesis of the present investigation that (there will be significant difference between continuance commitment dimension of public and private school teachers) is not proved.

The Mean and SD in the case of private school teachers on normative commitment dimension were found to be 27.48 and 3.54 , while in the case of public school teachers were found to be 25.46 and 5.07 respectively. The t-value between two means was found to b2.84 which was significant at 0.01 level of significance. Thus, the fourth underlined hypothesis of the present investigation that (there will be significant difference between normative commitment dimension of public and private school teachers) is proved.

\section{DISCUSSION}

The findings of the present study showed significant difference between organizational commitment of public and private school teachers. Further the results also showed the significant difference on each dimensions of organizational commitment except continuance commitment dimension. Private school teachers showed higher commitment on overall organizational commitment as well as on the each dimensions of organizational commitment as compared to the public school teachers. These findings are supported by several research studies such as; Misra, Ansari and Khan (2009) conducted the study to measure the organizational commitment among Government and private school teachers. They reported that the private school teachers showed higher organizational commitment as compared to the government school teachers. Further, Gupta and Gehlawat (2012) reported that Private school teachers significantly differ with Government school teachers and they possessed higher level of organizational commitment as compared to the Government school teachers.

\section{CONCLUSION}

Finally, it is concluded that private school teachers are more committed as compared to the public school teachers. There may be several reasons behind this result. Public school teachers have high job security in the schools while in the case of private school teachers they have very low job security. Due to the lack of job security in the private sector schools, teachers put higher commitment to the schools to secure their job for the long period of time. In the 
Indian education context, public sector schools constituted with very poor quality of working life as compared to the private schools. Private sector schools especially focused on teachers' quality of work life. Poor quality of work life developed boring, laziness, stress and physical distress etc among the teachers. These factors are adversely affected teachers' commitment at work place. Thus, the study gives enormous scope for the improvement of quality of work life in public sector schools to enhance the teachers' commitment.

\section{REFERENCES}

Allen, N.J. and Meyer, J.P. (1990). The Measurement and Antecedents of Affective, Continuance, and Normative Commitment to the Organization. Journal of Occupational Psychology 63, 1-18.

Beck, K. and Wilson, C. (2000). Development of affective organizational commitment. A crosssequential examination of change with tenure. Journal of Vocational Behaviour, 56, 114136.

Blau, C.J. \& Boal, K.R. (1987). Conceptualizing how job involvement and organizational commitment affect turnover and absenteeism. Academy of management review, April, p. 209.

Fresko, b., Kfir, d. and nasser, f. (1997). Predicting teacher commitment. Teaching and Teacher Education, 13(4), 429-438.

Kumari, S., \& Jafri, S. (2011). „Level of Organizational Commitment of Male and Female Teachers of Secondary Schools ${ }^{\text {ee }}$. Journal of Community Guidance \& Research, 28(1), $37-47$.

Gupta, M. and Gehlawat, M. (2013). A Study of the Correlates of Organizational Commitment Among Secondary School Teachers. Issues and Ideas in Education Vol. 1 March 2013 pp. 59-71.

Luthans, Fre; Wahl, La Vonne K. \& Steinhans, Corrol S. (1992). The importance of social support for employee commitment: A qualitative and quantitative analysis of bank tellers. Organization Development Journal, Vol. 10(9), pp. 1-10.

Mathew, T.C. (2003). A study of organizational commitment of degree college teachers in relation to work values, self-actualisation and leader behaviour of principals. Indian Educational Abstracts, 4(1), 86-87.

Maume, D.J. (2006). Gender differences in taking vacation time. Work and Occupations, 33(2), 161-190. 
Meyer, J. and Allen, N. (1991). A three-component conceptualization of organizational commitment. Human Resource Management Review, 1(1), 61-89.

Meyer, J. and Allen, N. (1997). Commitment in the workplace. Thousand Oaks, CA: SAGE Publications.

Miller, D. and Lee, J. (2001). The people make the process: commitment to employees decision making and performance. Journal of Management, 27(2), 163-189.

Misra, S., Ansari, N. and Khan, S.A. (2009). A comparative study of organizational commitment and organizational health among public and private school teachers. Indian Journal of Psychology and Mental Health, 3(5), 42-48.

Nagar, K. (2012). Organizational commitment and job satisfaction among teachers during times of burnout. Vikalpa: The Journal for Decision Makers, 37(2), 43-60.

Pedro, R. (1992). Preliminary models of teacher organizational commitment: Implications for restructuring the workplace. Retrieved from ERIC database. (ED275071)

Reichers, A.R. (1985). A review and reconceptualization of organizational commitment. Sharma, B.R. \& Singh, S. (1991). Determinants of organizational commitment. Management and Labour Studies, Vol. 16, pp. 63-75Academy of Management Review, pp. 465-476.

Shawkat, S. and Ansari, S.A. (2001). Organizational Commitment scale. Unpublished Ph. D thesis, A.M.U., Aligarh.

Sheldon, E.M. (1971). Investments and involvement as mechanisms producing commitment to the organization. Administrative Science Quarterly, 16, 143- 150.

Sherwin, D. (1972). Strategy for winning employee commitment. Harvard Business Review, May-June, pp. 3-47.

Suki, N., \& Suki, N. (2011). Job Satisfaction and Organizational Commitment: The Effect of Gender. International journal of psychology research, 6(5), 1-15.

Zilli, A. S., \& Zahoor, Z. (2012). Organizational Commitment among Male and Female Higher Education Teachers. Indian Journal of Psychology and Education, 2(1), 55-60. 